\title{
Temporal Change in Iron Content of Vegetables and Legumes in Australia: A Scoping Review
}

\author{
Erica Eberl ${ }^{1,+}\left(\mathbb{D}\right.$, Alice Shimin $\mathrm{Li}^{1,+}$, Zi Yin Joanne Zheng ${ }^{1} \mathbb{C}$, Judy Cunningham ${ }^{2}$ and Anna Rangan ${ }^{1, *} \mathbb{C}$ \\ 1 Charles Perkins Centre, The University of Sydney, Camperdown, NSW 2006, Australia; \\ eebe9552@uni.sydney.edu.au (E.E.); shli8956@uni.sydney.edu.au (A.S.L.); \\ zzhe5033@uni.sydney.edu.au (Z.Y.J.Z.) \\ 2 Curtin School of Population Health, Curtin University, Kent Street, Bentley, WA 6102, Australia; \\ judy.cunningham@curtin.edu.au \\ * Correspondence: anna.rangan@sydney.edu.au \\ + These authors contributed equally to this work.
}

check for updates

Citation: Eberl, E.; Li, A.S.; Zheng, Z.Y.J.; Cunningham, J.; Rangan, A. Temporal Change in Iron Content of Vegetables and Legumes in Australia: A Scoping Review. Foods 2022, 11, 56. https://doi.org/10.3390/ foods11010056

Academic Editor: Anthony Fardet

Received: 8 November 2021

Accepted: 20 December 2021

Published: 27 December 2021

Publisher's Note: MDPI stays neutral with regard to jurisdictional claims in published maps and institutional affiliations.

Copyright: (C) 2021 by the authors. Licensee MDPI, Basel, Switzerland. This article is an open access article distributed under the terms and conditions of the Creative Commons Attribution (CC BY) license (https:// creativecommons.org/licenses/by/ $4.0 /$ )

\begin{abstract}
Studies in UK and US have reported a temporal decline in the iron content of plant-based foods. Limited research on this topic has been conducted in Australia. The aim of this scoping review was to provide a comprehensive evaluation on the temporal change in iron content of Australian vegetables and legumes from 1900 onward. A systematic search of electronic databases, websites, backward reference searching, and Australian food composition tables was conducted. A total of 34 articles and six versions of Australian food composition databases published between 1930s to 2021, were included in this review. Overall, iron content of vegetables and legumes were assessed at limited time points and geographical origin, cultivars, sampling and analytical techniques varied across studies. The majority of vegetables had similar iron content between two or more timepoints but decreases of $30-50 \%$ were noted for sweet corn, red-skinned potatoes, cauliflower and green beans while increases of 150-300\% were seen for Hass avocadoes, mushrooms and silverbeet. More pronounced reductions in iron content were observed for legumes, with higher and more variable values reported pre-2000 compared to recent years. Due to limited data and variations in sampling and analytical techniques, no definitive conclusions could be established. As plant-based diets are becoming more popular, consistent monitoring of the nutrient composition of staple plant-based foods is strongly recommended.
\end{abstract}

Keywords: iron content; vegetable; legume; food composition; Australia

\section{Introduction}

Iron is commonly considered a mineral of concern for deficiency in people following vegetarian and vegan diets. While eliminating meat can be accomplished with minimal effect on total iron intake [1-3], vegetarian diets are associated with an increased consumption of phytate-containing vegetables, legumes and grains which hinder iron bioavailability $[3,4]$. A dependence on the less efficiently absorbed non-haem form as well as the presence of dietary components that inhibit intestinal solubility and absorption of iron $[5,6]$ increases the likelihood of low iron stores in people consuming plant-based diets [5]. Although no recent data is available on the prevalence of iron deficiency in Australia for those following a plant-based diet, the prevalence of iron deficiency in adult women, between 25-50 years of age, is estimated to be $20 \%$ [7].

There is a growing interest towards plant-based diets for health, ethical, environmental, and religious reasons [8]. Recent market research has shown a rise in the practice of vegetarianism in Australia, with the proportions of population consuming a plant-based diet increasing from $9.7 \%$ in 2012 to $12.1 \%$ in 2018 [9]. Based on the most recent national dietary survey, approximately one in eight Australians have inadequate iron intakes, with the highest at-risk group being females aged 14 to 50 years at $40 \%$ [10]. As females are 
twice as likely to be vegetarian or vegan than males and have higher iron requirements [11], it is particularly important to consider the sources of iron intake when changing to a plant-based diet.

There is concern that the mineral content of plant-based foods has declined in the past few decades. A 1997 study comparing nutrient data of vegetables and fruits in two UK food composition tables analysed in 1930s and 1980s found a significant decline in the levels of magnesium, calcium, copper, sodium, potassium and iron in those foods over time [12]. Since then, studies comparing historical US food composition data have also noted a marked temporal decrease in mineral content of plant-based foods [13,14]. A potential explanation for the apparent decrease in nutrient levels of horticultural produce has been proposed, linking to the idea of a "dilution effect" whereby cultivar selection for increased crop yield results in an accumulation of carbohydrate (starch, sugar, fibre) without a proportional increase in mineral content [14].

There has been limited research examining the trend in mineral content of plantbased foods in Australia. An investigation by Food Standards Australia New Zealand (FSANZ) observed no significant temporal change in six studied minerals, including iron, for fruits and vegetables sampled in the 1980s and early 2000s [15]. No recent studies have comprehensively assessed the temporal changes in iron content of Australian plant-based foods, and thus the research question was to examine whether the iron content of vegetables and legumes available in Australia has changed over time.

Using a scoping review approach, the aims of this paper were to firstly, examine the temporal changes of iron content in vegetables and legumes drawing on scientific and grey literature, and secondly, to explore any iron content changes for these foods in the national food composition databases over time. Findings from this study are particularly relevant in the current environment with growing numbers of people adopting a plant-based diet.

\section{Materials and Methods}

This review is based on the Arksey and O'Malley [16] framework and aligns with the Joanna Briggs Institute Scoping Review approach [17] and the Preferred Reporting Items for Systematic Reviews (PRISMA) extension for Scoping Review checklist [18].

\subsection{Eligibility Criteria}

To be included in this review, articles were required to report numerical data on the iron content of Australian legumes or vegetables focusing on the varieties from the 5 highest iron-contributing vegetable groups (potatoes; fruiting vegetables (excluding tomato); leaf and stalk vegetables; brassica vegetables; and peas and beans) identified in the Australian Health Survey 2011-12 (Supplementary Table S1). This included iron content from edible portions of crops, in a raw or dried form. As a further requirement for legume data, reported content should be from the edible fruit, seed or grain of legume including the embryo or de-hulled components, provided more than half of the legume fruit was analysed. All literature written in English and published between 1900 to 2020 were considered.

Papers were excluded if they did not report iron nutritive values, analysed components of vegetables or legume plant that were not commonly used for human consumption or were not sourced in Australia, only studied legume- or vegetable-based products (such as flour, pasta, plant-based milk, tofu), or dishes that involved more than one single type of vegetable or legume (mixed salad). Studies investigating the effect of a treatment variable that would unnaturally alter the iron content, for example heavy metal pollution, without including a control group were also excluded.

\subsection{Information Sources and Search}

To identify potentially relevant articles, the following literature databases were searched systematically from inception dates (year 1900 as earliest) to 10 December 2021: MEDLINE (Ovid), EMBASE (Ovid), Global Health (Ovid), Scopus, Web of Science CAB Abstracts and Core Collections, ANR Index and Archive (Informit). The search strategies were revised 
with the assistance of an academic liaison librarian from the University of Sydney and further refined through team discussion. The final search strategies for MEDLINE searches can be found in Supplementary Tables S2 and S3. Final search results were exported into EndNote X9 (Clarivate Analytics), and duplicates were removed.

A grey literature search was performed through hand-searching of websites of relevant organisations: Australian Export Grains Innovation Centre, Bean Growers Australia Limited, Department of Primary Industries and Regional Development's Agriculture and Food Division, FSANZ, Grains and Legumes Nutrition Council (GLNC), Grain Industry Association of Western Australia, Grains Research and Development Corporation, Horticulture Innovation Australia Ltd., Pulse Australia. FAO/INFOODS Global Food Composition Database for Pulses-version 1.0 was also screened for relevant data. Up to the first 100 results of keyword string searches created by the combination of keywords representing three main topics of interest (e.g., potato AND iron content AND Australia) were screened on Google and Trove (National Library of Australia database) in November 2020. Backward reference searching of included records was conducted.

Six versions of reference food composition databases including the Composition of Foods Australia (CoFA) 1989, Nutrient Tables for Use in Australia (NUTTAB) 1991-2, NUTTAB 1995, NUTTAB 2006, NUTTAB 2010 and Australian Food Composition DatabaseRelease 1.0 (2019) were examined to gather publicly accessible data on the iron contents of vegetables and legumes. Reference food composition databases published prior to 1989 were not included as these consisted largely of values obtained outside of Australia.

\subsection{Selection of Sources of Evidence}

All articles were independently screened by two reviewers [ASL and EE], first by title and abstract and then by full text. Disagreements in the literature selection process were resolved by consensus or through discussion with a third reviewer [AR].

\subsection{Data Charting Process and Data Items}

The data charting form was developed for this review and two reviewers [ASL and EE] charted the data on vegetables and legumes independently. Results were discussed and the data-charting forms were continuously updated in an iterative process to summarise key characteristics of included studies and relevant findings. The following data were charted: authorship, publication year, type of vegetable/legume, iron content (all converted to $\mathrm{mg} / 100 \mathrm{~g}$ ), sampling details (date and location, sample number, study method), and analytical method. For papers that did not specify the year of growth or sampling, the date was taken as the year of publication. Efforts were made to contact the author or affiliated organisation regarding any missing data in the included studies.

\subsection{Synthesis of Results}

The charted data were summarised within the individual vegetable and legume groupings to examine changes in iron content over time if multiple timepoints were available. For data obtained from the six Australian food composition databases, changes in iron content by vegetable or legume variety were examined between databases published between 1989 to 2019.

\section{Results}

\subsection{Study Selection}

A total of 19,538 articles were identified from literature databases, food composition tables, and grey literature searches (Figure 1). After removal of duplicates, 13,198 articles were screened based on title and abstract, which excluded 12,933 articles. Full text screening of 265 articles excluded a further 225 articles, mostly due to not analysing Australian vegetables or legumes, not reporting iron content with units of measure, or analysing a nonedible component of the vegetable or legume. In this case, 18 studies were excluded because they were unable to be retrieved after contacting library staff, affiliated organisations, and 
journals. The remaining 40 articles were considered eligible; 34 were primary analyses and 6 were reference food composition databases.
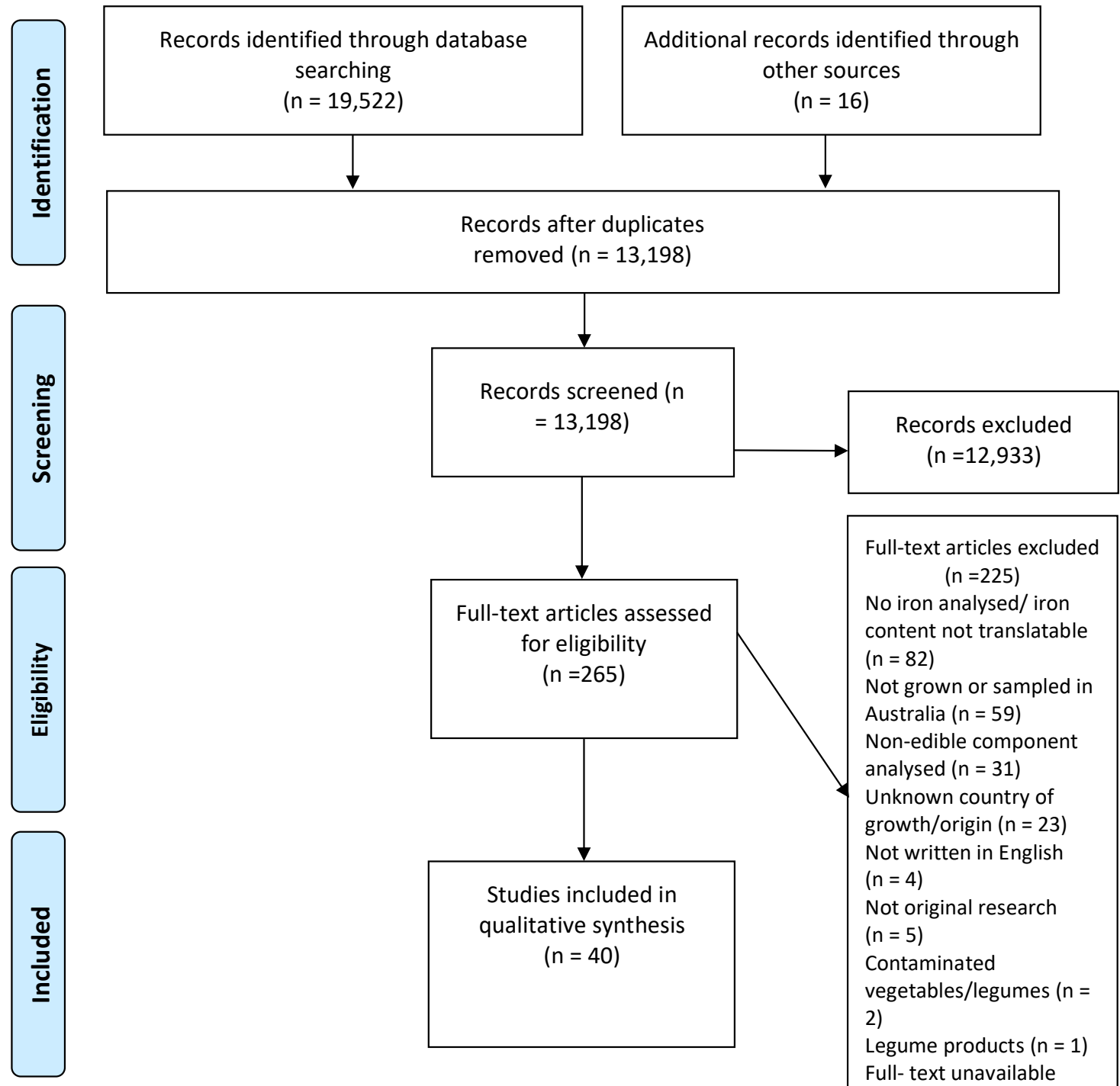

Full-text articles assessed for eligibility ( $n=265$ )

No iron analysed/ iron content not translatable ( $n=82$ )

Not grown or sampled in Australia ( $n=59$ ) Non-edible component analysed $(n=31)$ Unknown country of growth/origin ( $n=23$ ) Not written in English ( $n=4)$

Studies included in qualitative synthesis $(n=40)$

Not original research ( $n=5)$

Contaminated vegetables/legumes $(n=$ 2) Legume products $(n=1)$ Full- text unavailable $(n=18)$

Figure 1. PRISMA flowchart illustrating the systematic screening process performed for the scoping review.

\subsection{Study Characteristics}

In this case, 34 primary analysis reports sampled Australian grown or sourced vegetables and legumes between 1930 and 2021, with the majority of research conducted between 1980 and 2010 (Table 1). These studies provided iron values for a total of 56 vegetable types/cultivars within the top 5 iron-contributing vegetable groups and 21 legume types/cultivars. Of these, 16 vegetable and 8 legume types were analysed at two or more time points. 
Table 1. Key characteristics of studies reporting iron content of vegetables and legumes grown or sourced in Australia. Data were derived from raw, edible portion unless otherwise specified, rounded to the nearest one decimal place.

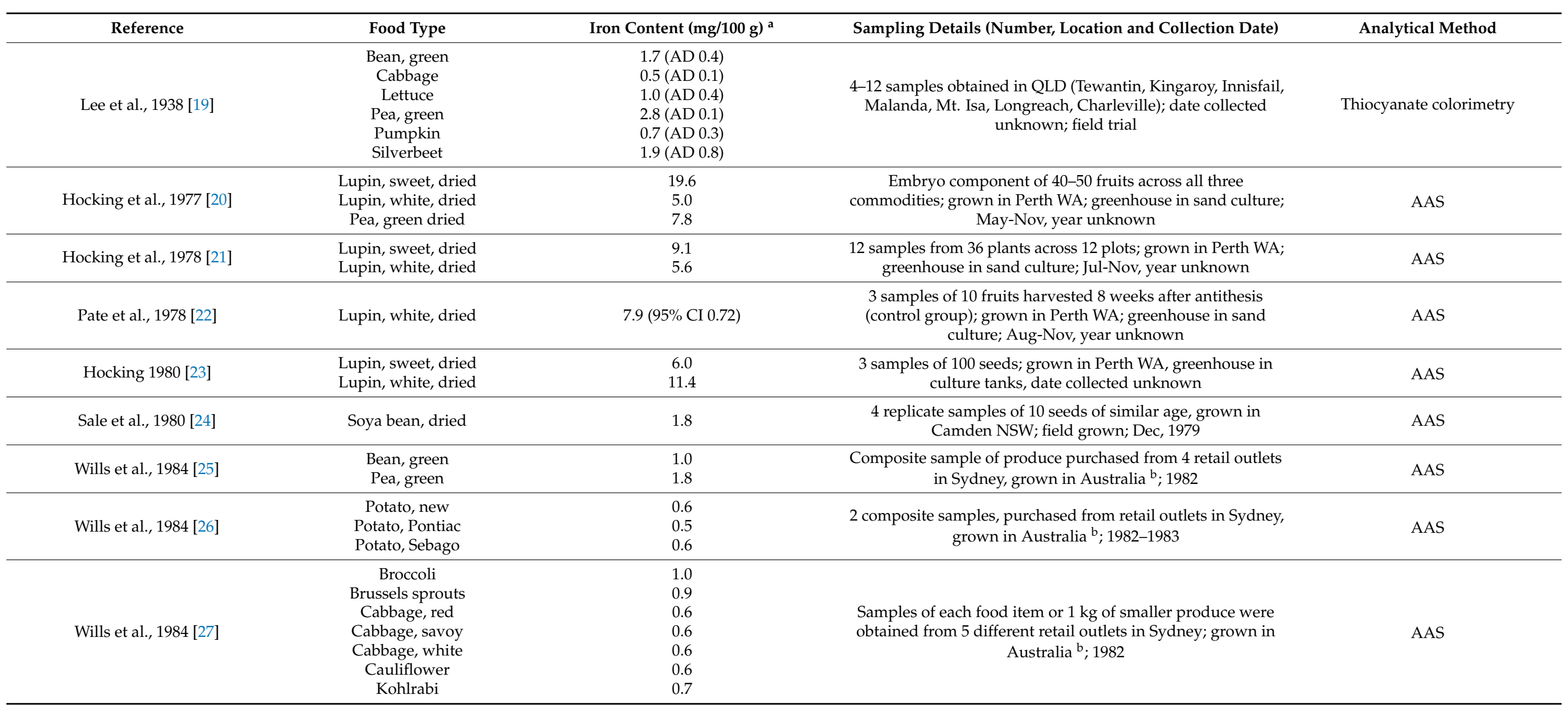


Table 1. Cont.

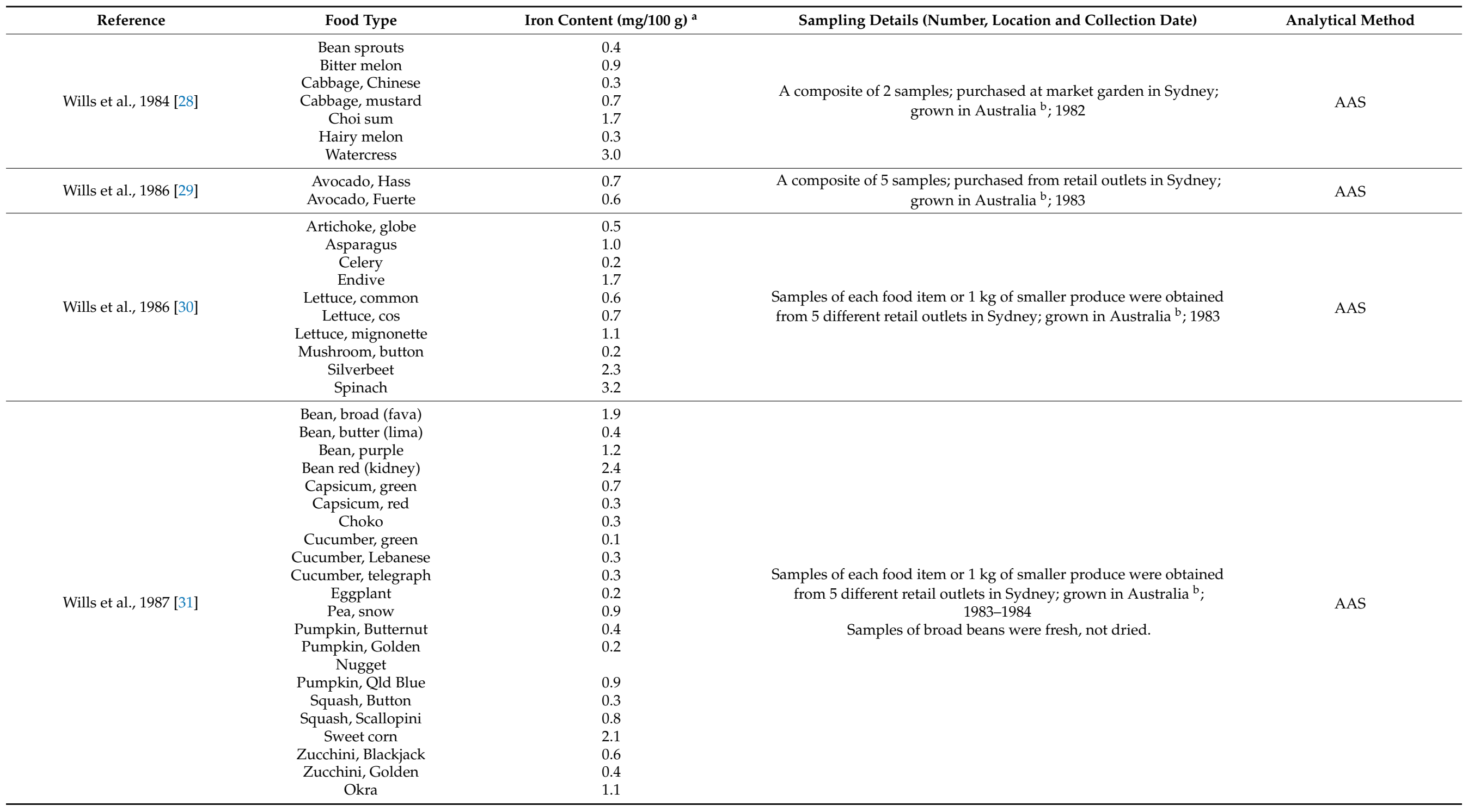


Table 1. Cont.

\begin{tabular}{|c|c|c|c|c|}
\hline Reference & Food Type & Iron Content $(\mathrm{mg} / 100 \mathrm{~g})^{a}$ & Sampling Details (Number, Location and Collection Date) & Analytical Method \\
\hline Hung et al., 1988 [32] & $\begin{array}{l}\text { Lupin, sweet, dried } \\
\text { Lupin, white, dried }\end{array}$ & $\begin{array}{l}5.2 \text { (R 2.6-7.6) } \\
4.3(\text { R } 3.0-4.6)\end{array}$ & $\begin{array}{l}22 \text { samples of sweet lupin seeds and } 11 \text { samples of white lupin seeds } \\
\text { collected from different locations in Victoria; field grown, date } \\
\text { collected unknown }\end{array}$ & ICP-AES \\
\hline Bolland et al., 1993 [33] & $\begin{array}{l}\text { Lupin, sweet, dried } \\
\text { Lupin, sweet, dried }\end{array}$ & $\begin{array}{l}4.6(\text { SE } 0.3) \\
5.3(\text { SE } 0.9)\end{array}$ & $\begin{array}{c}3 \text { samples grown in South Carrabin WA; field grown, May } 1987 \\
3 \text { samples grown in Badgingarra WA; field grown, May } 1987\end{array}$ & ICP-AES \\
\hline Petterson et al., 1997 [34] & $\begin{array}{c}\text { Cowpea, dried } \\
\text { Mung bean, green, dried } \\
\text { Mung bean, black, dried } \\
\text { Adzuki bean, dried } \\
\text { Bean, fava, dried } \\
\text { Pea, green dried } \\
\text { Bean, navy, dried } \\
\text { Bean, lima, dried } \\
\text { Lupin, sweet, dried } \\
\text { Lupin, white, dried } \\
\text { Lentil, dried } \\
\text { Chickpea, Kabuli, dried } \\
\text { Chickpea, Desi, dried } \\
\text { Pigeon pea, dried }\end{array}$ & $\begin{array}{c}5.9 \text { (R 5.2-6.4) } \\
4.9 \text { (R 4.8-5.2) } \\
6.6(\text { R 4.3-9.2) } \\
4.4 \\
9.6(\text { R 4.0-16.9) } \\
5.3 \text { (R 3.5-9.0) } \\
6.8(\text { R 5.6-9.3) } \\
5.7 \\
6.9(\text { R 3.1-15.0) } \\
2.7 \text { (R 2.1-4.4) } \\
65.5 \text { (R 4.3-341) } \\
5.7(\text { R 3.2-12.5) } \\
5.0 \text { (R 3.5-12) } \\
3.3 \text { (R 2.9-4.0) }\end{array}$ & $\begin{array}{l}\text { 1-535 samples collated from various sources, grown in Australia, date } \\
\text { collected unknown }\end{array}$ & Various \\
\hline Bolland et al., 2000 [35] & Bean, fava, dried & $\begin{array}{l}5.4(\text { SE } 0.06) \\
5.7 \text { (SE } 0.07) \\
6.1(\text { SE } 0.08)\end{array}$ & $\begin{array}{c}\text { Unspecified sample size, grown in South Kukerin WA 1997, East } \\
\text { Pingaring WA 1998, and West Pingaring WA 1998, respectively; field } \\
\text { grown }\end{array}$ & ICP-AES \\
\hline Cunningham et al., 2002 [15] & $\begin{array}{c}\text { Avocado, Hass } \\
\text { Bean, green } \\
\text { Broccoli } \\
\text { Cabbage, green } \\
\text { Capsicum, green } \\
\text { Capsicum, red } \\
\text { Cauliflower } \\
\text { Celery } \\
\text { Cucumber, Greenridge } \\
\text { Lettuce, iceberg } \\
\text { Mushroom, button } \\
\text { Pea, green } \\
\text { Potato, Coliban } \\
\text { Potato, Desiree } \\
\text { Pumpkin, Butternut } \\
\text { Pumpkin, Jarrahdale } \\
\text { Sweet corn } \\
\text { Zucchini, green }\end{array}$ & $\begin{array}{l}0.5 \\
1.0 \\
0.8 \\
0.4 \\
0.5 \\
0.3 \\
0.4 \\
0.3 \\
0.3 \\
0.6 \\
0.3 \\
1.8 \\
0.5 \\
0.2 \\
0.2 \\
0.3 \\
0.5 \\
0.4\end{array}$ & $\begin{array}{l}\text { 6-11 samples of each vegetable were purchased from different regions } \\
\text { (VIC, SA, QLD, NSW, WA, TAS); } 2000\end{array}$ & ICP-MS \\
\hline
\end{tabular}


Table 1. Cont.

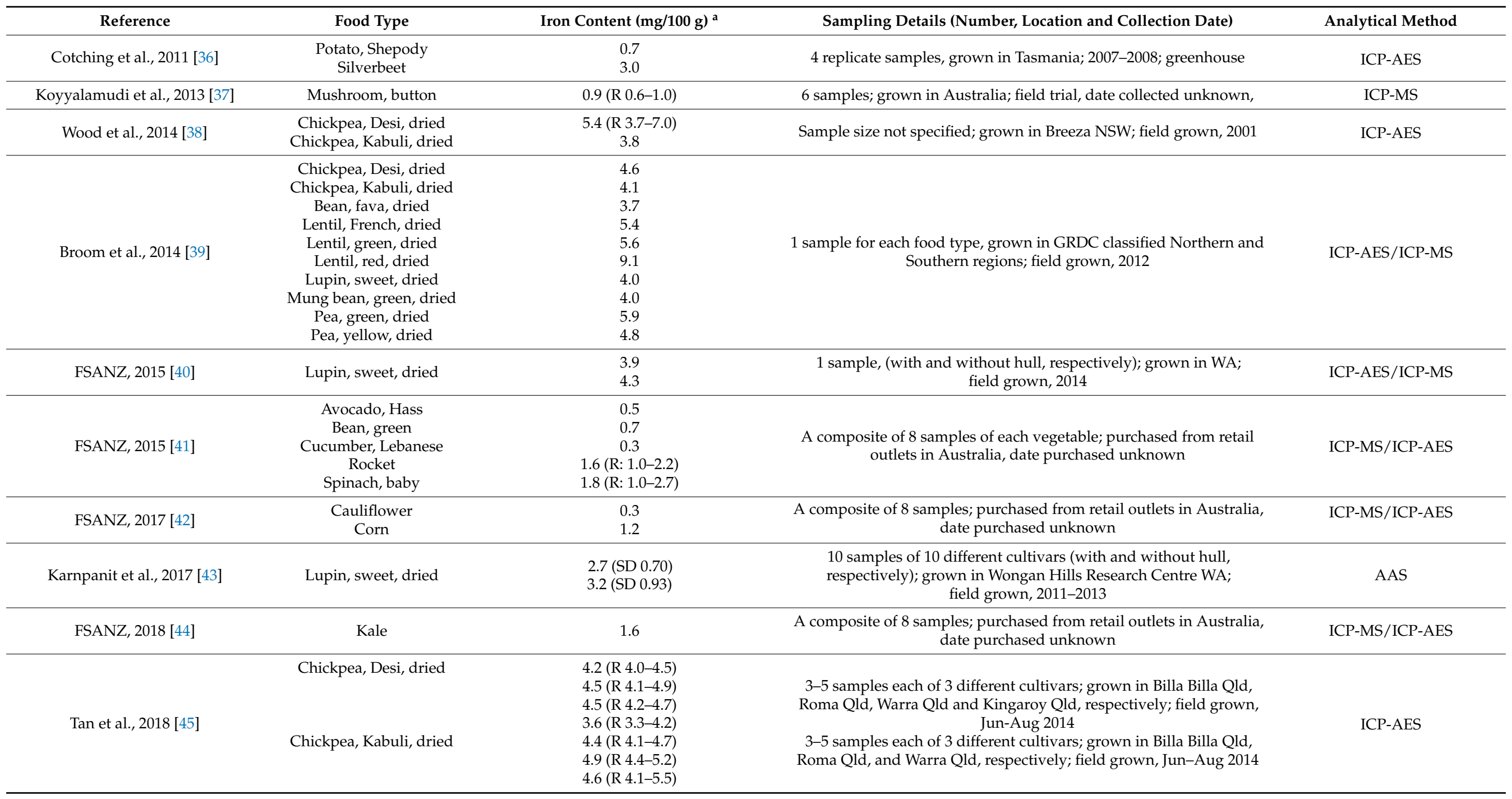


Table 1. Cont.

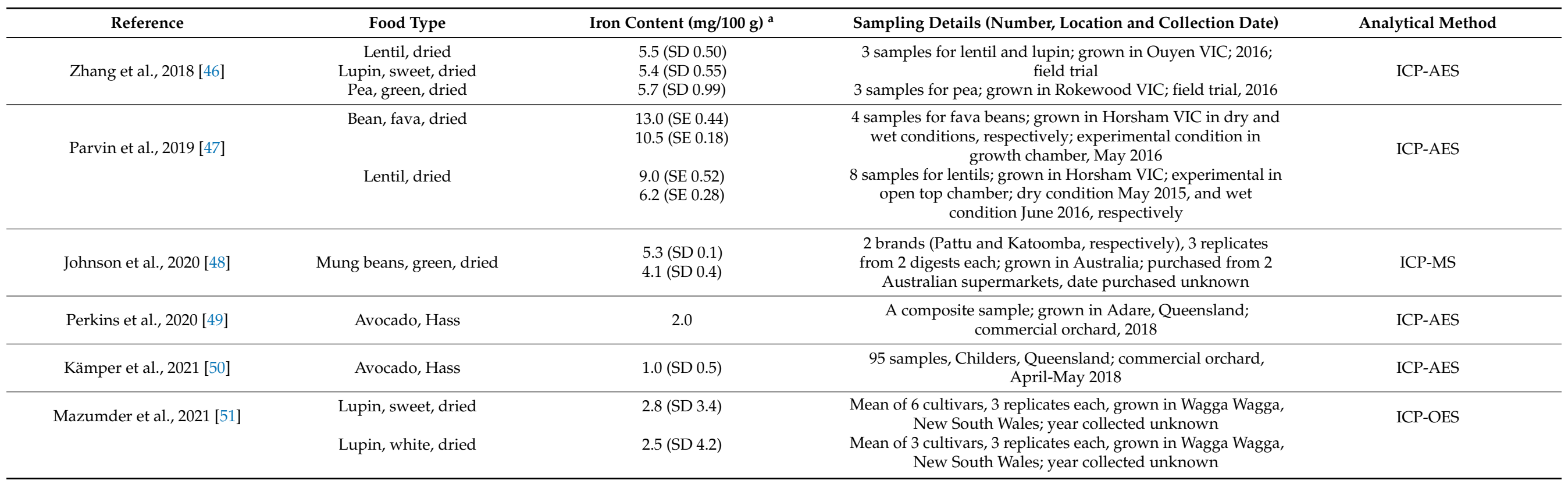

a Values expressed as mean with or without a measure of variability depending on the reference. ${ }^{b}$ Purchased in Sydney with growth location not specified, however samples were considered as Australian grown given that $>98 \%$ of total vegetables available at the time were locally produced. Abbreviations: AAS: atomic absorption spectroscopy; AD: average deviation; CI: Confidence Interval; FSANZ: Food Standards Australia New Zealand; ICP-AES: inductively coupled plasma atomic emission spectroscopy; ICP-MS: Inductively coupled plasma-mass spectrometry; ICP-OES: Inductively coupled plasma optical emisssion spectroscopy; R: range; SD: standard deviation; SE: standard error. 
Sampling varied among the studies, with most using a single or composite sample and reporting no statistical variability. The growing regions for vegetables and legumes were all within Australia but exact locations were not reported for all studies and nor were factors such as soil and fertiliser type. The majority of samples were collected in field, or at retail outlets although a small number were grown in greenhouse or in experimental conditions using an open-top or growth chamber. Analytical techniques used in the included studies differed over the years from thiocyanate colorimetry in the 1930s, atomic absorption spectroscopy (AAS) between 1970-1990, and inductively coupled plasma-mass spectrometry (ICP-MS) or inductively coupled plasma atomic emission spectroscopy (ICP-AES) from 2000 onwards. Data are summarised in Table 1.

\subsection{Changes in Iron Content Based on Scoping Review Data}

Temporal trends in iron content of vegetables and legumes, assessed using data from at least two time points (Table 1), are summarised in the sections below.

\subsubsection{Potatoes}

Pale-skinned and red-skinned potatoes were considered separately, as was carried out in food composition databases. For pale-skinned potatoes, iron content remained relatively stable between three timepoints; 1982 (Sebago $0.6 \mathrm{mg} / 100 \mathrm{~g}$ ) [26], 2000 (Coliban $0.5 \mathrm{mg} / 100 \mathrm{~g}$ ) [15] and 2007-2008 (Shepody $0.7 \mathrm{mg} / 100 \mathrm{~g}$ ) [36]. For red-skinned potatoes, a decrease was observed from $0.5 \mathrm{mg} / 100 \mathrm{~g}$ in 1982 (Pontiac) [26] to $0.2 \mathrm{mg} / 100 \mathrm{~g}$ in 2000 (Desiree) [15] although the cultivars differed between the timepoints.

\subsubsection{Stem and Leafy Vegetables}

An apparent increase in iron content of silverbeet was observed across three time points from $1.9 \mathrm{mg} / 100 \mathrm{~g}$ in 1938 [19] to $2.3 \mathrm{mg} / 100 \mathrm{~g}$ in 1983 [30] and $3.0 \mathrm{mg} / 100 \mathrm{~g}$ in 2007-2008 [36]. Iron content of lettuce was reported over three time points and ranged from $1.0 \mathrm{mg} / 100 \mathrm{~g}$ in 1938 (unspecified variety) [19], to $0.6 \mathrm{mg} / 100 \mathrm{~g}$ in both 1983 [30] and 2000 (common/iceberg) [15]. For celery, iron content remained similar between 1983 [30] and 2000 [15] at 0.2 and $0.3 \mathrm{mg} / 100 \mathrm{~g}$, respectively. No other stem or leafy vegetables were analysed at multiple timepoints.

\subsubsection{Fruiting Vegetables}

In this vegetable group, eight vegetable types were analysed for iron content at two or more time points. Iron content remained stable with little change between 1983/1984 [31] and 2000 [15] for butternut pumpkin $(0.4$ and $0.2 \mathrm{mg} / 100 \mathrm{~g})$, red $(0.3$ and $0.3 \mathrm{mg} / 100 \mathrm{~g})$ and green capsicum $(0.7$ and $0.5 \mathrm{mg} / 100 \mathrm{~g})$, and green zucchini $(0.4$ and $0.4 \mathrm{mg} / 100 \mathrm{~g})$, and between 1983/1984 [31] and 2015 [41] for Lebanese cucumber (0.3 and $0.3 \mathrm{mg} / 100 \mathrm{~g})$.

Mushroom, avocado and corn were additionally analysed at later timepoints. Button mushrooms ranged in iron content from 0.2 to $0.3 \mathrm{mg} / 100 \mathrm{~g}$ in 1983 [30] and 2000 [15], respectively, but higher in 2013 at $0.9 \mathrm{mg} / 100 \mathrm{~g}$ [37]. Hass avocado ranged from $0.5-0.7 \mathrm{mg} / 100 \mathrm{~g}$ between 1982 and 2015 [15,29,41], but higher values were reported in $2018(2.0 \mathrm{mg} / 100 \mathrm{~g})$ [49] and 2020 (1.0 mg/100 g) [50]. Corn showed the largest decline in iron content from $2.1 \mathrm{mg} / 100 \mathrm{~g}$ in 1983 [31] to $0.5 \mathrm{mg} / 100 \mathrm{~g}$ in 2000 [15] and $1.2 \mathrm{mg} / 100 \mathrm{~g}$ in 2017 [42]

\subsubsection{Brassica Vegetables}

Iron content of broccoli, cauliflower and cabbage was reported at two or more time points. For broccoli, iron contents were relatively similar in 1982 [27] and 2000 [15] (1.0 and $0.8 \mathrm{mg} / 100 \mathrm{~g}$, respectively). The iron content of cabbage was similar amongst varieties (red, savoy, white, green) and across time ranging from 0.4-0.6 mg/100 g from 1938 to $2000[15,19,27]$. Cauliflower iron concentrations reduced slightly from $0.6 \mathrm{mg} / 100 \mathrm{~g}$ in 1982 [27] to 0.4 and $0.3 \mathrm{mg} / 100 \mathrm{~g}$ in 2000 [15] and 2017 [42], respectively. 


\subsubsection{Beans and Peas (Green Beans and Peas)}

Green beans were first analysed in 1938 [19] with an iron content of $1.7 \mathrm{mg} / 100 \mathrm{~g}$ but lowered to $1.0 \mathrm{mg} / 100 \mathrm{~g}$ in both 1982 [25] and 2000 [15], and $0.7 \mathrm{mg} / 100 \mathrm{~g}$ in 2015 [41]. Similarly for green peas, iron content was highest in 1938 at $2.8 \mathrm{mg} / 100 \mathrm{~g}$ [19] and lower in 1982 [25] and 2000 [15] at $1.8 \mathrm{mg} / 100 \mathrm{~g}$ at both timepoints.

\subsubsection{Lentils (Dried)}

Amongst Australian-grown lentils, red, green, and French varieties were identified and analysed between 1997 and 2016. The highest iron concentration was reported in 1997 at $65.5 \mathrm{mg} / 100 \mathrm{~g}$ (unspecified variety) [34] but ranged from 5.4 (French) [39], 5.6 (green) [39] and 9.1 (red) [39] and 5.5-9.0 mg/100 g (unspecified varieties) in the 2010s [46,47].

\subsubsection{Chickpeas (Dried)}

Amongst chickpeas, both Desi and Kabuli varieties were analysed at multiple timepoints between 1997 and 2014. For Desi chickpea, iron levels ranged from $5.0 \mathrm{mg} / 100 \mathrm{~g}$ in 1997 [34] to 3.6-4.6 mg/100 $\mathrm{g}$ in 2010's [39,45] and for Kabuli chickpea, iron levels tended to range from $5.7 \mathrm{mg} / 100 \mathrm{~g}$ in 1997 [34] to $3.8 \mathrm{mg} / 100 \mathrm{~g}$ in 2001 [38], and 4.1-4.9 mg/100 in 2010s $[39,45]$.

\subsubsection{Other Legumes (Dried) (Peas, Fava bean, Mung Bean, Lupin)}

Dried green peas were analysed between 1977 and 2016 on four occasions, with the highest iron content reported in 1977 (7.8 mg/100 g) [20], followed by $5.3 \mathrm{mg} / 100 \mathrm{~g}$ in 1997 [34], and 5.7-5.9 mg/100 g in 2010s [39,46]. Other varieties of dried peas (yellow, pigeon, cow pea) were only analysed at a single time point. Fava beans (broad beans) were analysed at multiple timepoints, and iron content ranged from 5.4-9.6 mg/100 g in 1997 [34,35] and 1998 [35] to $3.7 \mathrm{mg} / 100 \mathrm{~g}$ in 2012 [39]. In 2016, iron values of 10.5-13.0 mg/100 g were reported for fava beans but in highly manipulated experimental conditions [47]. For green mung beans, the iron content varied from $4.9 \mathrm{mg} / 100 \mathrm{~g}$ in 1997 [34] to $4.0 \mathrm{mg} / 100 \mathrm{~g}$ in 2012 [39], and 4.1-5.3 $\mathrm{mg} / 100$ in 2020 [48].

The most common lupins consumed by humans, sweet lupin (Lupinus angustifolius) and white lupin (Lupinus albus), were both analysed at multiple timepoints. The iron content of sweet lupin ranged from $6.0-19.6 \mathrm{mg} / 100 \mathrm{~g}$ in the 1970s [20,21,23], $5.2 \mathrm{mg} / 100 \mathrm{~g}$ in 1980s [32]; $4.6-6.9 \mathrm{mg} / 100 \mathrm{~g}$ in 1990s [33,34], to $2.7-5.4 \mathrm{mg} / 100 \mathrm{~g}$ in $2010 \mathrm{~s}[40,43,46]$ and $2.8 \mathrm{mg} / 100 \mathrm{~g}$ in 2021 [51]. For white lupin, the iron content showed a decrease; from 5.0-11.4 mg/100 g in late 1970s [20-23], to $4.2-4.3 \mathrm{mg} / 100 \mathrm{~g}$ in 1980s [32], $2.7 \mathrm{mg} / 100 \mathrm{~g}$ in 1990s [34] and $2.5 \mathrm{mg} / 100 \mathrm{~g}$ in 2021 [51].

\subsection{Changes in Iron content in Australian Food Composition Databases 1989-2019}

Table 2 shows the changes in iron content as revealed in the Australian food composition databases for the vegetable groups and legumes for which data were available. For the majority of vegetables ( 35 out of $54,65 \%$ ) and all legumes (7 out of 7 ), iron content was only analysed at one timepoint and no temporal changes could be examined. For vegetables that were analysed at two or more time points $(n=19)$, the iron content decreased over time for six vegetables, remained the same ( \pm 0.1 to allow for rounding) for 12 , and increased for one vegetable. The largest reduction in iron content was found for sweetcorn; from 2.1 to $1.2 \mathrm{mg} / 100 \mathrm{~g}$ from 1989 to 2019 , followed by red-skinned potato (0.5 to $0.2 \mathrm{mg} / 100 \mathrm{~g})$, cauliflower $(0.6$ to $0.3 \mathrm{mg} / 100 \mathrm{~g})$ and green beans $(1.0$ to $0.7 \mathrm{mg} / 100)$. The only vegetable that revealed an increase in iron content was mushroom, from 0.2 to $0.5 \mathrm{mg} / 100 \mathrm{~g}$ between 1989 and 2019. 
Table 2. Iron content of vegetables and legumes reported in Australian reference food composition databases between 1989 to 2019

\begin{tabular}{|c|c|c|c|c|c|c|c|}
\hline Figure A1989. & Processing & CoFA1989 & NUTTAB1991-2 & NUTTAB1995 & NUTTAB2006 & NUTTAB2010 & AFCD2019 \\
\hline \multicolumn{8}{|l|}{ Potatoes } \\
\hline Potato, new & Raw & 0.6 & 0.6 & 0.6 & 0.6 & 0.6 & 0.6 \\
\hline Potato, Coliban (pale skin) & Raw & na & na & na & 0.4 & 0.5 & 0.5 \\
\hline Potato, Sebago (pale skin) & Raw & 0.6 & na & na & 0.6 & 0.6 & 0.6 \\
\hline Potato, pale skin (unspec) & Raw & 0.6 & 0.6 & 0.6 & 0.6 & $0.5^{\mathrm{a}}$ & 0.5 \\
\hline Potato, Desiree (red skin) & Raw & na & na & na & 0.2 & 0.2 & 0.2 \\
\hline Potato, Pontiac (red skin) & Raw & 0.5 & na & na & na & 0.5 & 0.5 \\
\hline Potato, red skin (unspec) & Raw & 0.5 & 0.5 & 0.5 & 0.3 & $0.2^{\mathrm{a}}$ & 0.2 \\
\hline Artichoke, globe & Raw & 0.5 & 0.5 & 0.5 & 0.5 & 0.5 & 0.5 \\
\hline Asparagus & Raw & 1.0 & 1.0 & 1.0 & 1.0 & 1.0 & 1.0 \\
\hline Celery & Raw & 0.2 & 0.2 & 0.2 & 0.2 & $0.3^{\mathrm{a}}$ & 0.3 \\
\hline Endive & Raw & 1.7 & 1.7 & 1.7 & 1.7 & 1.7 & 1.7 \\
\hline Lettuce, cos & Raw & 0.7 & 0.7 & 0.7 & 0.7 & 0.7 & 0.7 \\
\hline Lettuce, iceberg & Raw & 0.6 & 0.6 & 0.6 & $0.6^{\mathrm{a}}$ & 0.6 & 0.6 \\
\hline Lettuce, mignonette & Raw & 1.1 & 1.1 & 1.1 & 1.1 & 1.1 & 1.1 \\
\hline Silverbeet & Raw & 2.3 & 2.3 & 2.3 & 2.5 & 2.3 & 2.3 \\
\hline Spinach, English & Raw & 3.2 & 3.2 & 3.2 & 3.5 & 3.2 & 3.2 \\
\hline Watercress & Raw & 3.0 & 3.0 & 3.0 & 3.0 & 3.0 & 3.0 \\
\hline \multicolumn{8}{|l|}{ Fruiting vegetables } \\
\hline Avocado & Raw & 0.7 & 0.7 & 0.7 & $0.6^{\mathrm{a}}$ & 0.5 & $0.5^{\mathrm{a}}$ \\
\hline Capsicum, green & Raw & 0.7 & 0.7 & 0.7 & 0.6 & $0.6^{\mathrm{a}}$ & $0.5^{\mathrm{a}}$ \\
\hline Capsicum, red & Raw & 0.3 & 0.3 & 0.3 & 0.3 & $0.3^{\mathrm{a}}$ & 0.3 \\
\hline Choko & Raw & 0.3 & 0.3 & 0.3 & 0.3 & 0.3 & 0.3 \\
\hline Cucumber, common & Raw & 0.1 & 0.1 & 0.1 & $0.2^{\mathrm{a}}$ & 0.2 & 0.2 \\
\hline Cucumber, Lebanese & Raw & 0.3 & 0.3 & 0.3 & 0.3 & 0.3 & $0.3^{\mathrm{a}}$ \\
\hline Cucumber, telegraph & Raw & 0.3 & 0.3 & 0.3 & 0.3 & 0.3 & 0.3 \\
\hline Eggplant & Raw & 0.2 & 0.2 & 0.2 & 0.2 & 0.2 & 0.2 \\
\hline Melon, bitter & Raw & 0.9 & 0.9 & 0.9 & 0.9 & 0.9 & 0.9 \\
\hline Melon, hairy & Raw & 0.3 & 0.3 & 0.3 & 0.3 & 0.3 & 0.3 \\
\hline Mushroom & Raw & 0.2 & 0.2 & 0.2 & $0.3^{\mathrm{a}}$ & 0.3 & $0.45^{\mathrm{a}}$ \\
\hline Okra & Raw & 1.1 & 1.1 & 1.1 & na & 1.1 & 1.1 \\
\hline Pumpkin, Butternut & Raw & 0.4 & 0.4 & 0.4 & $0.3^{\mathrm{a}}$ & 0.3 & 0.3 \\
\hline Pumpkin, Golden Nugget & Raw & 0.2 & 0.2 & 0.2 & 0.2 & 0.2 & 0.2 \\
\hline
\end{tabular}


Table 2. Cont.

\begin{tabular}{|c|c|c|c|c|c|c|c|}
\hline Figure A1989. & Processing & CoFA1989 & NUTTAB1991-2 & NUTTAB1995 & NUTTAB2006 & NUTTAB2010 & AFCD2019 \\
\hline \multicolumn{8}{|l|}{ Fruiting vegetables } \\
\hline Pumpkin, Jarrahdale & Raw & na & na & na & 0.1 & 0.1 & 0.1 \\
\hline Pumpkin, Queensland Blue & Raw & 0.9 & 0.9 & 0.9 & 0.9 & 0.9 & 0.9 \\
\hline Pumpkin, unspec & Raw & 0.5 & 0.5 & 0.5 & 0.2 & 0.4 & 0.4 \\
\hline Squash, button, yellow & Raw & 0.3 & 0.3 & 0.3 & 0.3 & 0.3 & 0.3 \\
\hline Squash, scallopini, green & Raw & 0.8 & 0.8 & 0.8 & 0.8 & 0.8 & 0.8 \\
\hline Sweet corn & Raw & 2.1 & 2.1 & 2.1 & $1.0^{\mathrm{a}}$ & 1.0 & $1.2^{\mathrm{a}}$ \\
\hline Zucchini, green & Raw & 0.6 & 0.6 & 0.6 & $0.5^{\mathrm{a}}$ & 0.5 & 0.5 \\
\hline Zucchini, golden & Raw & 0.4 & 0.4 & 0.4 & 0.4 & 0.4 & 0.4 \\
\hline \multicolumn{8}{|l|}{ Brassica vegetables } \\
\hline Broccoli & Raw & 1.0 & 1.0 & 1.0 & $0.9^{\mathrm{a}}$ & 0.8 & 0.8 \\
\hline Brussels sprout & Raw & 0.9 & 0.9 & 0.9 & 0.9 & 0.9 & 0.9 \\
\hline Cabbage, Chinese & Raw & 0.3 & 0.3 & 0.3 & 0.3 & 0.3 & 0.3 \\
\hline Cabbage, Chinese flowering & Raw & 1.7 & 1.7 & 1.7 & 1.7 & 1.7 & 1.7 \\
\hline Cabbage, mustard & Raw & 0.7 & 0.7 & 0.7 & 0.7 & 0.7 & 0.7 \\
\hline Cabbage, red & Raw & 0.6 & 0.6 & 0.6 & 0.6 & 0.6 & 0.6 \\
\hline Cabbage, savoy & Raw & 0.6 & 0.6 & 0.6 & 0.6 & 0.6 & 0.6 \\
\hline Cabbage, white/common & Raw & 0.6 & 0.6 & 0.6 & $0.5^{\mathrm{a}}$ & 0.5 & 0.5 \\
\hline Kohlrabi & Raw & 0.7 & 0.7 & 0.7 & 0.7 & 0.7 & 0.7 \\
\hline \multicolumn{8}{|l|}{ Beans and peas (green) } \\
\hline Bean, green & Raw & 1.0 & 1.0 & 1.0 & $1.1^{\mathrm{a}}$ & 1.1 & $0.7^{\mathrm{a}}$ \\
\hline Bean sprouts & Raw & 0.4 & 0.4 & 0.4 & 0.4 & 0.4 & 0.4 \\
\hline Pea, green & Raw & 1.8 & 1.8 & 1.8 & $1.8^{\mathrm{a}}$ & 1.8 & 1.8 \\
\hline Pea, snow & Raw & 0.9 & 0.9 & 0.9 & 0.9 & 0.9 & 0.9 \\
\hline \multicolumn{8}{|l|}{ Legumes } \\
\hline Bean, fava & Raw (fresh) & 1.9 & 1.9 & 1.9 & 1.9 & 1.9 & 1.9 \\
\hline Bean, haricot & Dried & na & 6.4 & 6.4 & 6.4 & 6.4 & 6.4 \\
\hline Bean, kidney & Dried & na & 5.6 & 5.6 & 5.6 & 5.6 & 5.6 \\
\hline Bean, lima & Dried & na & 5.7 & 5.7 & 5.7 & 5.7 & 5.7 \\
\hline Lentil, red, brown, green & Dried & na & 7.5 & 7.5 & 7.5 & 6.7 & 6.7 \\
\hline Pea, split & Dried & na & 3.8 & 3.8 & 3.8 & 3.8 & 3.8 \\
\hline Soya bean & Dried & na & 9.5 & 9.5 & 9.5 & 9.5 & na \\
\hline
\end{tabular}

a the time when iron value were obtained from a new sample analysis. AFCD2019: Australian Food Composition Database Release 1 (2019); CoFA1989: Composition of Foods Australia (1989); na: not available; unspec: unspecified variety, estimate of average values. 


\section{Discussion}

This scoping review provides a comprehensive evaluation on the change in iron content of Australian vegetables and legumes using both published and grey literature data sources. Overall, the number of studies conducted were limited, with the first study published in 1938, followed by the majority of studies being conducted after 1980. Many vegetables and legumes were only analysed at one timepoint while others such as chickpeas and lupins were analysed at more than three different timepoints. Based on these data, our findings indicate that temporal changes in iron content of vegetables and legumes varied by individual type. For most vegetables, iron content remained relatively unchanged or decreased slightly. The vegetables with the largest declines over time included sweet corn, red-skinned potatoes, cauliflower, and fresh green beans (30-50\%) while increases were noted for Hass avocadoes, mushrooms and silverbeet (150-300\%). More pronounced reductions in iron content were observed for legumes, with early values, in particular pre-2000, typically being much higher and more variable than recent ones.

In addition, the changes in iron values based on vegetables and legumes included in six Australian food composition databases published between 1989 to 2019 were assessed. The majority were only analysed at one time point although a large number of vegetables were analysed during the early $1980 \mathrm{~s}$ for inclusion in the first Australian database and again in 2000 by FSANZ [15]. For vegetables analysed at more than one timepoint, most iron values were unchanged or slightly lower over time. The largest differences were seen in sweetcorn, red-skinned potato, and cauliflower, which approximately halved, and for mushroom which approximately doubled.

However, direct comparability of iron content among vegetable and legume sampled is not possible due to numerous differences in sampling such as geographic, environmental, and seasonal variability, variety of genotypes and cultivars sampled, and different analytical techniques used to measure iron content among studies. These factors have been shown to result in greater than 2-fold variability in iron content for vegetables and legumes [14].

Our studies sourced vegetables and legumes from different geographic regions of Australia, with exposure to variable climatic and soil conditions that are known to affect plant iron concentrations [52,53]. Differences in seasonal and growth conditions also affect iron content, for example, greenhouses and growth chambers offer more protection and control over climate, soil, crop health and pest infestations than field production [54]. This may explain the higher iron content values observed in our review for lupin grown in greenhouses in studies conducted before 1980 than in later field trials.

Use of different genotypes and cultivars during sampling and over time can contribute to variations in iron content of $2-4$ fold [14]. For example, iron content varied 3-4 fold among samples and varieties of a single crop species such as soybeans $(6-20 \mathrm{mg} / 100 \mathrm{~g})$ and common beans (Phaseolus vulgaris 3.1-12.1 mg/100 g) $[13,14,55,56]$. In the vegetables and legumes reported here, specific cultivar names were often not reported and it is unknown whether or not commodities purchased at different times were the same cultivar or a new one, even if the same common name was used.

Analytical techniques have evolved over time with improvements in accuracy and precision. Early wet chemistry methods, such as colorimetry in the 1930s [19], were replaced with atomic absorption spectrophotometry (AAS) in the mid 1970s [14], and then ICP-Atomic Emission Spectrometry, ICP-Optical Emission Spectrometry and ICP-Mass Spectrometry after 1990. These analytical methods differ in their degree of extraction of iron from plant genotypes as well as their ability to identify contamination, with ICP methods having greater accuracy and specificity [14]. Since soils contain much higher concentrations of iron than plants [13], tiny amounts of unremoved soil can increase iron content values considerably. This may explain the higher iron values reported when older analytical methods were applied.

Considering the differences in sampling and analytical methods, it is likely that the variation in iron content of vegetables and legumes observed in this review (at most 2-fold), falls within expected natural ranges with no clear evidence of a temporal change. Previous 
studies examining changes in iron content of horticultural produce over time, have reported inconsistent results $[12,13,57,58]$. Mayer (1997) found a significant overall decrease of $22 \%$ between 1930s to 1980s in vegetables using the UK food composition database, although the presence of anomalies of measurement or sampling, changes in the food system, changes in the varieties grown or changes in agricultural practice could not be discounted [13]. Davis et al. (2004) found similar results (27\% overall decrease) using US composition from 1950 to 1999 although approximately a quarter of garden crops tested showed an increase in iron content over time [14]. A re-analysis of these UK and US data by White and Broadley (2005), adjusting for moisture content found no statistical differences in iron content between 1930s and 1980s or later [55]. Similarly, Bruggraber et al. (2012) did not find significant changes in iron content when a group of vegetables in the UK were re-analysed in 2000 compared with food composition values from the 1930s and 1980s (difference of 11\%) [56].

This scoping review has a number of strengths and limitations. A key strength of this study was the good coverage of data from both published and grey literature sources through extensive search on numerous electronic databases with no limitation on timeframe, relevant websites, and food composition databases. Several potentially eligible records were unavailable although extensive efforts were made to retrieve these through liaising with university library staff and contacting affiliated organisations. Direct comparability of iron content was not possible and no statistical analyses were conducted due to a paucity of available data, a lack of studies reporting some measure of iron content variability, and the large heterogeneity in sampling and analytical methods used.

It has been argued that comparison of historical food composition tables is not a reliable way to determine changes in nutrient composition of foods over time as the data may not be representative of domestically grown produce and is a reflection of the food supply available at the time [14]. Nevertheless, food composition data are used to estimate nutrient intakes of the population and it is therefore important to assess whether shifts have occurred over time in the nutrient content of staple foods consumed. As many vegetables and legumes are grown domestically in Australia, food composition data is thus more likely to reflect nutrient content of Australian produce. This highlights the need to maintain the currency of the database for monitoring the nutritional content of Australian produce. For example, the iron content of legumes and some commonly consumed leafy green vegetables have not been updated since the 1980s, and as plant-based diets are gaining popularity, this is likely to become increasingly relevant.

In the context of the Australian diet, vegetable and legume products/dishes on average contributed $9.6 \%$ and $1.1 \%$, respectively, to the total iron intake of Australians aged two years and above [59]. Adults obtain more iron from vegetables and legumes than children (11.4\% versus $7.8 \%$ ), and females more than males (11.9\% versus 9.7\%) [59]. As both decreases and increases were noted in iron content of some commonly consumed vegetables, this is unlikely to affect the overall dietary iron intake at a population level. Although contribution of iron from vegetables and legumes could potentially be higher for vegetarians and vegans, any small decrease in iron content of vegetables and legumes could be easily managed through increasing consumption of widely available iron-fortified foods such as cereal and bread.

\section{Conclusions}

In conclusion, this scoping review provides a comprehensive evaluation on the change in iron content of Australian vegetables and legumes. It highlights a paucity of data on iron content over the past 100 years with most being collected between the 1980 and 2018 . Based on the available limited data, and due to variations in sampling, analytical techniques and likely differences in growing location and season, no definitive temporal trends could be established. As more people are following plant-based or vegetarian diets, consistent monitoring of the nutrient composition of staple plant-based foods is strongly recommended. 
Supplementary Materials: The following are available online at https:/ / www.mdpi.com/article/10 .3390 / foods11010056/s1, Table S1: Contribution of iron intake in Australians by vegetables groups and legumes based on the Australian Health Survey 2011-2 (ABS, 2014); Table S2: Search strategy used on MEDLINE via Ovid interface for literature on iron content of vegetables; Table S3: Search strategy used on MEDLINE via Ovid interface for literature on iron content of legumes.

Author Contributions: Conceptualization and methodology, A.R.; data curation, E.E., A.S.L. and A.R.; writing-original draft preparation, E.E. and A.S.L.; writing—review and editing, E.E., A.S.L., Z.Y.J.Z., J.C., A.R.; supervision, A.R. All authors have read and agreed to the published version of the manuscript.

Funding: This research received no external funding.

Institutional Review Board Statement: Not applicable.

Informed Consent Statement: Not applicable.

Data Availability Statement: Data is contained within the article or supplementary material.

Acknowledgments: We would like to acknowledge the help of liaison librarian Monica Cooper.

Conflicts of Interest: The authors declare no conflict of interest.

\section{References}

1. Craig, W.J.; Mangels, A.R. Position of the American Dietetic Association: Vegetarian diets. J. Am. Diet. Assoc. 2009, 109, 1266-31282. [CrossRef]

2. Davey, G.K.; Spencer, E.A.; Appleby, P.N.; Allen, N.E.; Knox, K.H.; Key, T.J. EPIC-Oxford: Lifestyle characteristics and 396 nutrient intakes in a cohort of 33,883 meat-eaters and 31,546 non meat-eaters in the UK. Public Health Nutr. 2003, 6, 259-269. [CrossRef] [PubMed]

3. Bowman, S.A. A Vegetarian-Style Dietary pattern is associated with lower energy, saturated fat, and sodium intakes; and higher whole grains, legumes, nuts, and soy intakes by adults: National Health and Nutrition Examination Surveys 2013-2016. Nutrients 2020, 12, 2668. [CrossRef] [PubMed]

4. Worsley, A.; Skrzypiec, G. Teenage vegetarianism: Prevalence, social and cognitive contexts. Appetite 1998, 30, 151-170. [CrossRef] [PubMed]

5. Hunt, J.R.; Roughead, Z.K. Nonheme-iron absorption, fecal ferritin excretion, and blood indexes of iron status in women consuming controlled lactoovovegetarian diets for 8 weeks. J. Am. Diet. Assoc. 1999, 69, 944-952. [CrossRef]

6. Hunt, J.R. Bioavailability of iron, zinc, and other trace minerals from vegetarian diets. Am. J. Clin. Nutr. 2003, 78, 633s-639s. [CrossRef]

7. Ahmed, F.; Coyne, T.; Dobson, A.; McClintock, C. Iron status among Australian adults: Findings of a population based study in Queensland, Australia. Asia Pac. J. Clin. Nutr. 2008, 17, 40-47.

8. Pribis, P.; Pencak, R.C.; Grajales, T. Beliefs and attitudes toward vegetarian lifestyle across generations. Nutrients 2010, 2, 523-531. [CrossRef]

9. Roy Morgan Research. The Slow but Steady Rise of Vegetarianism in Australia. Available online: http://www.roymorgan.com/ findings/vegetarianisms-slow-but-steady-rise-in-australia-201608151105 (accessed on 4 November 2021).

10. Australian Bureau of Statistics; Food Standards Australia New Zealand. Australian Health Survey: Usual Nutrient Intakes, 2011-2012; 4364.0.55.008; Australian Bureau of Statistics: Canberra, Australia, 2015.

11. National Health and Medical Research Council; New Zealand Ministry of Health. Iron. In Nutrient Reference Values for Australia and New Zealand Including Recommended Dietary Intakes; National Health and Medical Research Council: Canberra, Australia, 2006; pp. 171-175.

12. Mayer, A.-M. Historical changes in the mineral content of fruits and vegetables. Br. Food J. 1997, 99, 5. [CrossRef]

13. Davis, D.R.; Epp, M.D.; Riordan, H.D. Changes in USDA Food Composition Data for 43 Garden Crops, 1950 to 1999 . J. Am. Coll. Nutr. 2004, 23, 669-682. [CrossRef]

14. Marles, R.J. Mineral nutrient composition of vegetables, fruits and grains: The context of reports of apparent historical declines. $J$. Food Compos. Anal. 2017, 56, 93-103. [CrossRef]

15. Cunningham, J.H.; Milligan, G.; Trevisan, L. Minerals in Australian Fruits and Vegetables-A Comparison of Levels between the 1980s and 2000; Food Standards Australia New Zealand: Canberra, Australia, 2002.

16. Arksey, H.; O'Malley, L. Scoping studies: Towards a methodological framework. Int. J. Soc. Res. Methodol. 2005, 8, 19-32. [CrossRef]

17. Aromataris, E.; Munn, Z. (Eds.) JBI Manual for Evidence Synthesis; JBI: Adelaide, Australia, 2020. [CrossRef]

18. Tricco, A.C.; Lillie, E.; Zarin, W.; O’Brien, K.K.; Colquhoun, H.; Levac, D.; Moher, D.; Peters, M.D.J.; Horsley, T.; Weeks, L.; et al. PRISMA Extension for Scoping Reviews (PRISMA-ScR): Checklist and Explanation. Ann. Int. Med. 2018, 169, 467-473. [CrossRef] [PubMed]

19. Lee, D.H.K.; Robinson, K.; Newman, A.; Rheuben, R.P. Report of an Investigation of the Mineral Content of some Queensland Foods in Fifth Report of the Advisory Council on Nutrition; Commonwealth of Australia: Canberra, Australia, 1938; pp. 48-55.

20. Hocking, P.J.; Pate, J.S. Mobilization of Minerals to Developing Seeds of Legumes. Ann. Bot. 1977, 41, 1259-1278. [CrossRef] 
21. Hocking, P.; Pate, J. Accumulation and distribution of mineral elements in the annual lupins Lupinus albus L. and Lupinus angustifolius L. Aust. J. Agric. Res. 1978, 29, 14. [CrossRef]

22. Pate, J.S.; Hocking, P.J. Phloem and xylem transport in the supply of minerals to a developing legume (Lupinus albus L.) fruit. Ann. Bot. 1978, 42, 911-921. [CrossRef]

23. Hocking, P.J. Redistribution of nutrient elements from cotyledons of two species of annual legumes during germination and seedling growth. Ann. Bot. 1980, 45, 383-396. [CrossRef]

24. Sale, P.W.G.; Campbell, L.C. Patterns of mineral nutrient accumulation in soybean seed. J. Field Crops Res. 1980, 3, 157-163. [CrossRef]

25. Wills, R.B.H.; Evans, T.J.; Lim, J.S.K.; Scriven, F.M.; Greenfield, H. Composition of Australian foods. 25. Peas and beans. Food Technol. Aust. 1984, 36, 512-514.

26. Wills, R.B.H.; Lim, J.S.K.; Greenfield, H. Variation in nutrient composition of Australian retail potatoes over a 12-month period. J. Sci. Food Agric. 1984, 35, 1012-1017. [CrossRef]

27. Wills, R.B.H.; Lim, J.S.K.; Greenfield, H. Composition of Australian foods. 23. Brassica vegetables. Food Technol. Austr. 1984, 36, 176-177.

28. Wills, R.B.H.; Wong, A.; Scriven, F.M.; Greenfield, H. Nutrient composition of Chinese vegetables. J. Agric. Food Chem. 1984, 32, 413-416. [CrossRef]

29. Wills, R.B.H.; Lim, J.S.K.; Greenfield, H. Composition of Australian foods. 31. Tropical and sub-tropical fruit. Food Technol. Austr. 1986, 38, 118-123.

30. Wills, R.B.H.; Lim, J.S.K.; Greenfield, H. Composition of Australian foods. 32. Leafy, stem and other vegetables. Food Technol. Austr. 1986, 38, 416-417, 421.

31. Wills, R.B.H.; Lim, J.S.K.; Greenfield, H. Composition of Australian foods. 39. Vegetable fruits. Food Technol. Austr. 1987, 39, 488-490.

32. Hung, T.V.; Handson, P.D.; Amenta, V.C.; Kyle, W.S.A.; Yu, R.S.T. Mineral composition and distribution in lupin seeds and in flour, spray dried powder and protein isolate produced from the seeds. J. Sci. Food Agric. 1988, 45, 145-154. [CrossRef]

33. Bolland, M.D.A.; Jarvis, R.J.; Coates, P.; Harris, D.J. Effect of phosphate fertilisers on the elemental composition of seed of wheat, lupin, and triticale. Comm. Soil. Sci. Plant Anal. 1993, 24, 1991-2014. [CrossRef]

34. Petterson, D.S.; Sipsas, S.; Mackintosh, J.B. The Chemical Composition and Nutritive Value of Australian Pulses; Grains Research and Development Corporation: Kingston, Australia, 1997.

35. Bolland, M.; Siddique, K.; Brennan, R. Grain yield responses of faba bean (Vicia faba L.) to applications of fertiliser phosphorus and zinc. Austr. J. Exp. Agric. 2000, 40, 849-857. [CrossRef]

36. Cotching, W.; Coad, J. Metal element uptake in vegetables and wheat after biosolids application. J. Solid Waste Technol. Manag. 2011, 37, 75-82. [CrossRef]

37. Koyyalamudi, S.R.; Jeong, S.-C.; Manavalan, S.; Vysetti, B.; Pang, G. Micronutrient mineral content of the fruiting bodies of Australian cultivated Agaricus bisporus white button mushrooms. J. Food Compos. Anal. 2013, 31, 109-114. [CrossRef]

38. Wood, J.A.; Knights, E.J.; Campbell, G.M.; Choct, M. Differences between easy- and difficult-to-mill chickpea (Cicer arietinum L.) genotypes. Part II: Protein, lipid and mineral composition. J. Sci. Food Agric. 2014, 94, 1446-1453. [CrossRef]

39. Broom, M.; Salman, H.; Aley, G. A Comprehensive Nutrient Content Database of Grains and Legumes Produced in Australia: Pilot Study Results; Grains and Legumes Nutrition Council and Grain Growers Limited: Canberra, Australia, 2014.

40. Food Standards Australia New Zealand. Australian Sweet Lupin; Food Standards Australia New Zealand: Canberra, Australia, 2015.

41. Food Standards Australia New Zealand. 2014-2015 Key Foods Program; Food Standards Australia New Zealand: Canberra, Australia, 2015.

42. Food Standards Australia New Zealand. 2017 Key Foods Analytical Program; Food Standards Australia New Zealand: Canberra, Australia, 2017.

43. Karnpanit, W.; Coorey, R.; Clements, J.; Benjapong, W.; Jayasena, V. Calcium, Iron and Zinc Bioaccessibilities of Australian Sweet Lupin (Lupinus angustifolius L.) Cultivars. J. Agric. Food Chem. 2017, 65, 4722-4727. [CrossRef]

44. Food Standards Australia New Zealand. 2018 Food Composition Analytical Program; Food Standards Australia New Zealand: Canberra, Australia, 2018.

45. Tan, G.Z.H.; Das Bhowmik, S.S.; Hoang, T.M.L.; Karbaschi, M.R.; Long, H.; Cheng, A.; Bonneau, J.P.; Beasley, J.T.; Johnson, A.A.T.; Williams, B.; et al. Investigation of baseline iron levels in Australian chickpea and evaluation of a transgenic biofortification approach. Front. Plant Sci. 2018, 9, 788. [CrossRef] [PubMed]

46. Zhang, Y.Y.; Panozzo, J.; Hall, M.S.; Ajlouni, S. Bioaccessibility of some essential minerals in three selected Australian pulse varieties using an in vitro gastrointestinal digestion model. J. Food Sci. 2018, 83, 2873-2881. [CrossRef] [PubMed]

47. Parvin, S.; Uddin, S.; Tausz-Posch, S.; Armstrong, R.; Fitzgerald, G.; Tausz, M. Grain mineral quality of dryland legumes as affected by elevated $\mathrm{CO}_{2}$ and drought: A FACE study on lentil (Lens culinaris) and faba bean (Vicia faba). Crop Pasture Sci. 2019, 70, 244-253. [CrossRef]

48. Johnson, J.; Collins, T.; Power, A.; Chandra, S.; Skylas, D.; Portman, D.; Panozzo, J.; Blancard, C.; Naiker, M. Antioxidative properties and macrochemical composition of five commercial mungbean varieties in Australia. Legume Sci. 2020, 2, e27. [CrossRef]

49. Perkins, M.; Usanase, D.; Zhang, B.; Joyce, D.; Coates, L. Impact injury at harvest promotes body rots in 'Hass' avocado fruit upon ripening. Horticulturae 2020, 6, 11. [CrossRef] 
50. Kämper, W.; Ogbourne, S.M.; Hawkes, D.; Trueman, S.J. SNP markers reveal relationships between fruit paternity, fruit quality and distance from a cross-pollen source in avocado orchards. Sci. Rep. 2021, 11, 20043. [CrossRef]

51. Mazumder, K.; Biswas, B.; Kerr, P.G.; Blanchard, C.; Nabila, A.; Golder, M.; Aziz, M.G.; Farahnaky, A. Comparative assessment of nutritional, thermal, rheological and functional properties of nine Australian lupin cultivars. Sci. Rep. 2021, 11, 1-14. [CrossRef]

52. Bear, F.E.; Toth, S.J.; Prince, A.L.P. Variation in Mineral Composition of Vegetables; The Soil Science Society of America: Madison, WI, USA, 1949; pp. 380-384.

53. Tüzen, M.; Özdemir, M.; Demirbaş, A. Study of heavy metals in some cultivated and uncultivated mushrooms of Turkish origin. Food Chem. 1998, 63, 5. [CrossRef]

54. Aghili, F.; Khoshgoftarmanesh, A.H.; Afyuni, M.; Mobli, M. Mineral and ascorbic acid concentrations of greenhouse- and field-grown vegetables: Implications for human health. Int. J. Veg. Sci. 2012, 18, 64-77. [CrossRef]

55. Organization for Economic Cooperation and Development. Revised consensus document on compositional considerations for new varieties of soy bean [Glycine $\max$ (L.) Merr.]: Key food and feed nutrients, anti-nutrients, toxicants and allergens. In Proceedings of the Joint Meeting of the Chemicals Committee and the Working Party on Chemicals, Pesticides and Biotechnology, Paris, France, April 2012.

56. Organization for Economic Cooperation and Development. Consensus document on compositional considerations for new varieties of common bean (Phaseolus vulgaris L.): Key food and feed nutrients, anti-nutrients and other constituents. In Proceedings of the Joint Meeting of the Chemicals Committee and the Working Party on Chemicals, Pesticides and Biotechnology, Paris, France, April 2012.

57. White, P.J.; Broadley, M.R. Historical variation in the mineral composition of edible horticultural products. J. Horticult. Sci. Biotechnol. 2005, 80, 660-667. [CrossRef]

58. Bruggraber, S.; Chapman, T.; Thane, C.; Olson, A.; Jugdaohsingh, R.; Powell, J. A re-analysis of the iron content of plant-based foods in the United Kingdom. Br. J. Nutr. 2012, 108, 1-8. [CrossRef] [PubMed]

59. Australian Bureau of Statistics. Australian Health Survey: Nutrition First Results_Foods and Nutrients; ABS: Canberra, Australia, 2014. 